\title{
International Trade and Terror Relationship in Turkey
}

\author{
Şennur SEZGİN (https://orcid.org/0000-0002-4551-1563), Department of Economics, Eskişehir Osmangazi
} University, Turkey; e-mail: sennursezgin@ogu.edu.tr

\section{Türkiye'de Ticaret Hacmi ve Terör İlişkisi}

\begin{abstract}
In this study, the effect of terrorism on international trade is examined in the case of Turkey. Between 1980 and 2015, along with many important political and scientific developments towards the development of international trade, international trading has begun to reach certain limitations with the terrorist channel. International trade has reached the highest levels in history with globalization phenomenon. International trade has remarkably expanded with the help of widespread internet use information technologies especially in the trade of services. Along with these positive developments, international terrorism has a negative impact on world trade. There is strong evidence that the increase in terrorist incidents led to a decline on international trade. This study focuses on whether terrorism affects Turkey's foreign trade. In doing so, between 1970 and 2016, the sensitivity of foreign trade to terrorism was measured by the concept of elasticity.
\end{abstract}

Keywords : World Trade, Terrorism, Trade Volume, Turkey, Economic Growth.

JEL Classification Codes : F10, F43, H56.

$\ddot{\mathbf{O} z}$

$\mathrm{Bu}$ çalışmada, terörizmin uluslararası ticarete olan etkisi Türkiye özelinde incelenmektedir. 1980-2015 yılları arasında uluslararası ticaretin gelişmesi yolunda çok önemli siyasi ve bilimsel gelişmeler olmakla beraber artan terör olayları nedeniyle uluslararası ticarete belirli sınırlamalar gelmeye başlamıştır. Küreselleşme olgusuyla birlikte uluslararası ticaret olabildiğince genişlemeye başlamıştır. İnternet ve bilişim teknolojilerindeki gelişimde ticaretin çok daha hızlı kolay yapılmasını sağlamıştır. Özellikle ülkelerarası hizmet ticaretinde çok hızlı büyümeler meydana gelmiştir. Bu olumlu gelişmelerle birlikte uluslararası terörizm dünya ticareti üzerine olumsuz etkide bulunmaktadır. İlgili dönemde terör olaylarının artması ticari faaliyetlerde azalmaya yol açtığına dair güçlü deliller vardır. Bu çalışma terörizmin Türkiye'nin dış ticaretini etkileyip etkilemediğine odaklanmaktadır. Bunu yapmak içinde 1970-2016 yılları arasında dış ticaretin teröre karşı duyarlılığı esneklik kavramı ile ölçülmüştür.

\section{Anahtar Sözcükler $\quad$ ： Dünya Ticareti, Terörizm, Ticaret Hacmi Türkiye, Ekonomik} Büyüme. 


\section{Terrorism and International Trade Relationships}

The academic work on terrorism has been done for a long time, but after 9/11 2001, it has increased much more. Especially, the effects of terrorism on the economy have attracted many scholars' attention. The global war on terror has led to increased security all over the world, which has made international trade costlier. While the cost of terrorism in the whole world in 2000 was 4.93 billion dollars, in 2014, the cost of terrorism rose by $\$$ 52.9 billion (calculated by IEP).

Yet despite the renewed attention to the field, much remains to be clarified and integrated with what we already know from the economics of terrorism. It is also very important to examine terrorism that has caused such costs on the country's economies. For this reason, the effects of terrorism on foreign trade will be examined in this study. Although there are many studies analyzing the effects of terrorism on foreign trade, this study is different from them. Previous studies have focused on how terror affects foreign trade and have often used gravity models. In this study, it is tried to measure whether foreign trade is sensitive to terrorism. Within it, the concept of elasticity is used.

This study aims to investigate the effects of terrorism on foreign trade between the years 1970-2016. To do this, the study used the case of Turkey and elasticity analysis will be performed. The terrorism data required for this analysis will be taken from the global terrorist index prepared by the University of Maryland. Foreign trade data is obtained from the World Development Indicators. It was concluded that Turkey's foreign trade is not sensitive to terrorism.

In the next section, it will be discussed how terrorism influences foreign trade and the development of terrorism and foreign trade in the world between 1970 and 2016 will be discussed. In the following section, previous studies will be reviewed and then the terrorist trade index will be established. In the last section, the index will be applied to Turkey. Turkey's foreign trade in the years 1970-2016 will be analyzed whether it is susceptible to terrorism.

\section{How Terrorism Effect International Trade? Development of Foreign Trade and Terrorism}

It is necessary to define terror before moving on to how terrorism affects trade. We adopt Enders and Sandler's (1999) view of terrorism as "the premeditated use or threat of use of extra-normal violence or brutality by sub-national groups to obtain a political, religious, or ideological objective through intimidation of a huge audience, usually not directly involved with the policymaking that the terrorists seek to influence." In economic studies of terrorism, this is the most frequently used definition. Because these issues are intensely emotional and extremely visual, the loss of life and climate of fear produced have profound impact on general human well-being. Its three main elements are: (a) the use of extreme violence, (b) the "underground" nature of terrorist acts, individuals, and 
organizations, and (c) publicity, i.e., the intended effect on a broad audience, possibly through the media.

Among other effects, such threats reduce investments, impact both capital formation and employment. To gain international attention to their activities, terrorists often disproportionately target tourism, transportation or foreign direct investment (FDI). In turn, this affects a targeted nation's exports and imports. Therefore, we anticipate a negative relationship between terrorist activity and trade volume, as violence and war usually cost extra for operations, while terrorism may influence trade, depending on time and place. Terrorism affects trade volume in many ways. First, the cost of carrying out economic activities is increasing because terrorist activities threaten security. Depending on the size of the terrorist attacks, people may become increasingly confused, nervous, or generally feel less secure. Therefore, terrorism can lead to changes in the consumption and production habits of an individual (for example, tourism and shopping habits, and the desire to travel on public transport), disrupts existing business plans and thus international trade. Nevertheless, the insecurity that terror emerges can be a direct negative impact on trade. Since the economic impact of terrorist attacks and shoots is so unpredictable, current business plans can be outdated quickly, so firms often face greater risks. This insecurity can reduce the attractiveness of this market to international producers (Nitchs \& Shumacker, 2004).

Secondly, security measures will increase if terrorist incidents increase. With the introduction of strict rules, which often involve extensive inspections and sometimes border shutdowns, trade will become more expensive. In international trade there will be more waiting on the border gates, many material and time losses will emerge. For instance, after the September 11 attacks, the US closed its border gates and the tugs lasting 1 minute on the Canadian-ABD border were held for 20 hours. In these cases, the transaction costs will increase. Home transactions may be substituted for international commerce. And trade may also be diverted toward countries with less demanding border inspections. Third, terrorism may directly damage traded goods, either as collateral damage or as the target of terrorist attacks. Consequently, trading costs and the volume of trade will decline (Li, 2009). Although the goal of many terrorist attacks is not direct economic damage, there are increasingly actions taken to paralyze the country's economy. Attacks on oil pipelines in recent years are an example of this.

In this part of the article, we will examine the course of world trade volume and terrorist incidents. Table 1 was made for this. Table 1 presents the development of world trade and terrorist incidents between 1970-2016 based on 1970.

It is observed that there is a slow increase in world trade volume between 1970 and 1980. From 1980 onwards trading volume is seen to increase more rapidly due to the impact of globalization. This increase continued steadily until the 2008 crisis, and the world trade volume, which was 21,743 in 2008 , declined to 15,824 in 2009 . In 2016 , it caught the precrisis level. 
Table: 1

Word Trade and Terror Index (1970-2016)

\begin{tabular}{|c|c|c|}
\hline Years & World Trade Volume Index & World Terror Index \\
\hline 1970 & 100 & 100 \\
\hline 1971 & 120 & 100 \\
\hline 1972 & 159 & 200 \\
\hline 1973 & 222 & 100 \\
\hline 1974 & 346 & 550 \\
\hline 1975 & 400 & 450 \\
\hline 1976 & 461 & 500 \\
\hline 1977 & 491 & 150 \\
\hline 1978 & 448 & 750 \\
\hline 1979 & 477 & 1.050 \\
\hline 1980 & 704 & 4.750 \\
\hline 1981 & 888 & 6.100 \\
\hline 1982 & 950 & 6.700 \\
\hline 1983 & 974 & 12.500 \\
\hline 1984 & 1.165 & 13.150 \\
\hline 1985 & 1.257 & 9.250 \\
\hline 1986 & 1.208 & 6.150 \\
\hline 1987 & 1.585 & 7.900 \\
\hline 1988 & 1.692 & 9.350 \\
\hline 1989 & 1.785 & 9.850 \\
\hline 1990 & 2.296 & 8.500 \\
\hline 1991 & 2.255 & 9.050 \\
\hline 1992 & 2.447 & 10.650 \\
\hline 1993 & 2.915 & 8.000 \\
\hline 1994 & 2.694 & 7.600 \\
\hline 1995 & 3.731 & 6.950 \\
\hline 1996 & 4.353 & 7.500 \\
\hline 1997 & 4.871 & 13.400 \\
\hline 1998 & 4.739 & 5.650 \\
\hline 1999 & 4.350 & 4.500 \\
\hline 2000 & 5.356 & 5.800 \\
\hline 2001 & 4.735 & 6.400 \\
\hline 2002 & 5.704 & 5.600 \\
\hline 2003 & 7.590 & 4.150 \\
\hline 2004 & 10.462 & 6.450 \\
\hline 2005 & 12.385 & 8.500 \\
\hline 2006 & 14.655 & 12.500 \\
\hline 2007 & 18.055 & 16.150 \\
\hline 2008 & 21.743 & 9.150 \\
\hline 2009 & 15.824 & 9.300 \\
\hline 2010 & 19.493 & 7.150 \\
\hline 2011 & 24.462 & 8.150 \\
\hline 2012 & 25.325 & 16.100 \\
\hline 2013 & 26.266 & 20.800 \\
\hline 2014 & 26.026 & 41.750 \\
\hline 2015 & 22.855 & 47.450 \\
\hline 2016 & 22.210 & 41.000 \\
\hline
\end{tabular}

Table 1 and Figure 1 also show us the development of terrorist incidents in the world. The number of terrorist incidents was obtained from the Global Terrorism Database (2017). It is based on the number of terrorist attacks killed by 10 or more people. According to this, we see that in the early 1980's the number of terrorist attacks is very high. For example, in 1983 there is a 13.501 terrorist attacks that killed 10 or more people. This number has declined in the $90 \mathrm{~s}$, and in 1997 it increased to 13.400 again. In the following year, the terrorist activity which was reduced to half again in 1998, rose to 16.150 in 2007 . The number of fatalities from terror events that have declined since then has reached 16,000 again in 2012. After this date, the rapidly increasing number of terrorist attacks has increased by almost 2.5 times to 47,450 in 2015 . 
Figure: 1

World Trade and Terror Index (1970-2016)

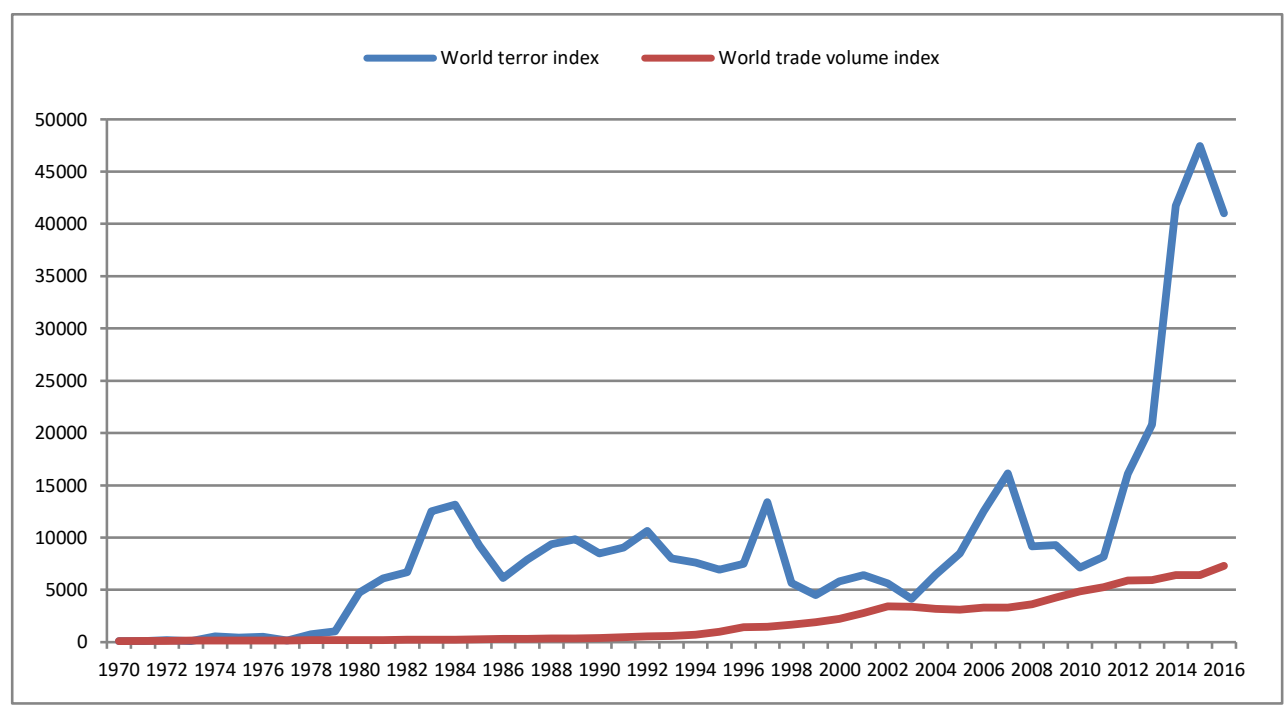

As a result, as seen in Figure 1, while the world trade is steadily increasing, terror activities are in an irregular course. However, after 2012, it is observed that the terrorist activities have increased very sharply.

\section{Previous Studies}

Thera are a few numbers of studies have been conducted showing the effects of terrorism on the economy. Such studies are Sezgin and Sezgin (2011), Gries et.al. (2011) and Sezgin et.al (2008) showed the effects of terrorism on the whole economy and regional economies. But this study will focus on the effects of terrorism on foreign trade. Terrorism and massive acts of violence can be considered to have a negative impact on international trade. Many of the empirical studies on this issue support this view. To test the effect of terrorism on trade, academicians employ the gravity model of international trade. International trade economists usually employ the gravity model to estimate the normal level of trade between states. The model posits that bilateral trade is a function of incomes, populations and distance between countries. When we add the terror variable to this model, we get the models that measure terrorism's effects on bilateral trade. One of the first studies on this subject is Nitsch and Schumacher (2004). In this study, more than 200 countries were included between the years 1960-1993, and the inter-country trade and terrorism relations was analyzed the "augmented gravity model". They have found that terrorist acts reduce international trade volume. The same is true of political instability and military conflicts. Their lower bound estimate of the direct effects suggests that a doubling in the number of terrorist incidents is associated with a decrease in bilateral trade by about 6 percent. 
Fratianni ve Kang (2006) developed the analysis of Nitsch ve Schumacher (2004) study in two perspectives. The first one, extended the study period between 1980 and 1999 and found that the terror variable was ineffective. They thought that this different result could be due to the period differences between the two studies. Secondly, they investigate how the terrorist impact on bilateral flows interact with geographic distance. To analyze this, they looked at the interaction of terror dummy variable with distance and common boundary dummy variable. As a result, terrorist-related trade costs tend to decrease as the distance between trading partners increases, while sharing a common border tends to increase the cost of terrorism over bilateral trade.

Another study on this subject is Bloomberg and Hess (2004). In this study, they looked at the cost of violence on bilateral trade flows. The period they dealt with was 19681999. They used ITERATE data to measure international terrorist activities. They also considered external conflicts, revolutions, ethnic civil war. As a result, they have found that any kind of violence, even at different levels, has a negative effect on trade. In addition, Bloomberg and Hess (2004) compared trade mitigation effects of violence with custom tariff rates. International terrorism leads to a trade cost equal to between $1 \%$ and $3 \%$ of the tariffs, while total violence has equivalent to a tariff that varies from $8 \%$ to $19 \%$.

In their study, Pham and Doucouliagos (2017) investigated whether the effects of terrorism in a country affected trade in neighboring countries. By addressing more than 160 countries from 1976 to 2014 and provided strong evidence that terrorist attacks on one nation's neighboring countries have significantly reduced bilateral trade. Every additional terrorist attack in a neighboring country reduces bilateral trade by an average of about $0.013 \%$, which causes a decrease of about US \$ 6.4 million in total trade. The adverse effects of terrorist incidents on trade are higher in sub-Saharan regions. Negative trade effects are existing for all sorts of terrorism and even zero-loss terrorist incidents. The negative effects of terrorist attacks on bilateral trade can be effective until after five years.

There are studies that do not support these views. Quan Li (2009) re-examine the effect of terrorism on trade. Previous studies have ignored the direction of terrorist attacks, failed to control for dyad-specific unobserved characteristics, and treated pairs of countries at different development stages equally. His study corrects these issues. Between 1968 and 2000, he applied the countries and methods dealt with by Nitsch and Schumacher. Unlike the others, test the implications of controlling for dyad-specific unobservable, political ties between governments of country pairs and subsamples based on development stage. As a result, he found no consistent evidence that the total number of terrorist incidents within countries reduce bilateral trade flows. In other words, terrorism may not always have negative effects on bilateral trade. They pointed out that this effect depends on the developmental stages of the countries, especially the heterogeneity of the two countries.

\section{Trade-Terrorist Evaluation Index (TTEI)}

As mentioned in the section above, the effects of terrorism on trade are measured by gravity models. In our work, the sensitivity of foreign trade to terrorism will be measured 
based on Khan and Yosuf (2017) study. Between the years 1970-2016 to make these measurements will be taken in case of Turkey. Following four steps are involved in the measurement of the TTEI.

International Trade $(T)=f($ terrorist attack $(T E))$

Step 1: total trade volume

The total trade volume is the sum of exports and imports of a country in a given year.

Total trade volume $=$ exports + imports

Step 2: trade growth rate $(\Delta \mathrm{TR})$

The trade growth rate $(\Delta \mathrm{TR})$ is defined as the difference between the trade volume of a present year and the trade volume of the previous year and then divided this value by the trade volume of the previous year.

The formula of the trade volume growth rate is as follows

Trade growth rate $=\left(\frac{T R_{x}-T R_{x-1}}{T R_{x-1}}\right) * 100$

where Tx is used for current year trade volume, while Tx-1 is used for the previous year trade volume.

Step 3: terrorism growth rate $(\Delta \mathrm{TE})$

The growth rate $(\triangle \mathrm{TE})$ is defined as the difference between the number of TE (terrorism) incidents of a present year and the number of terrorist attacks in previous year. Then it is divided by the number of TE incidents of the same previous year.

The mathematical formula of the given definition is as below:

$$
\Delta T E=\left(\frac{T E_{x-} T E_{x-1}}{T E_{x-1}}\right) * 100
$$

where TEx in the above equation shows the TE in current year, while TEx -1 represents the TE in previous year.

Step 4: trade-terrorist evaluation analysis

For further study, the coefficient of elasticity $(\varepsilon)$ is calculated and the first derivative of function 1 can be written as below:

$$
f^{\prime}(T E)=\frac{\Delta f(T E)}{\Delta T E}=\frac{\Delta T R}{\Delta T E}
$$


Based on above equations, the trade-terrorist evaluation analysis is measured as the trade growth rate divided by the terror growth rate.

The general formula of the said definition as below:

Trade terrorist evaluation index $=\frac{\% \Delta T R}{\% \Delta T E}$

There are three possible scenarios of the Equation (6):

a) If the value of TTEI is greater than 1, it shows that the responsive of teror-trade is more sensitive.

b) If the value of TTEI is less than 1, then it means that the response of teror-trade is less sensitive.

c) If the value of TTEIis equal to 1, then it explains that the response of teror-trade is unitary.

\section{The Application of Trade-Terrorist Evaluation Index (TTEI): The Case of Turkey}

In this section, we are applying the TTEI index to Turkey for the years between 1970 and 2016. Table 2 shows the detail of trade volume, number of terrorist attack and TTEI index of the Turkish economy. Trade growth rate of the Turkish economy is positive for 35 years and negative for 11 years in the period. Foreign trade volume, which was 1.5 billion dollars in 1970, increased steadily and reached to 10 billion dollars in 1980. Turkey changes the foreign trade regime after 1980 and began to follow an open trade policy after this date, the volume of foreign trade seems to increase much more rapidly. The volume of foreign trade, which was 35 billion dollars in 1990, has increased by a thousand \% and reached 403 billion dollars in 2013. After that date, trade volume declined to 341 billion dollars in 2016. 
Table: 2

TTE Index: Turkish Economy

\begin{tabular}{|c|c|c|c|c|c|c|c|c|c|}
\hline Years & $\begin{array}{c}\text { Export } \\
(\text { million \$) }\end{array}$ & $\begin{array}{c}\text { Import } \\
(\text { million \$) }\end{array}$ & $\begin{array}{c}\text { Total Trade } \\
\text { (billion \$) }\end{array}$ & dtr & $\begin{array}{c}\text { Trade Growth } \\
\%\end{array}$ & Terror & dte & $\begin{array}{c}\text { Terror Growth } \\
\% \\
\end{array}$ & Trade Terror Index \\
\hline 1970 & 588 & 948 & 1,54 & & & 1,00 & & & \\
\hline 1971 & 677 & 1.171 & 1,85 & 0,20 & 20,27 & 1,00 & 0,00 & 0,00 & .. \\
\hline 1972 & 885 & 1.563 & 2,45 & 0,32 & 32,49 & 1,00 & 0,00 & 0,00 & .. \\
\hline 1973 & 1.317 & 2.086 & 3,40 & 0,39 & 39,04 & 1,00 & 0,00 & 0,00 & .. \\
\hline 1974 & 1.532 & 3.778 & 5,31 & 0,56 & 56,02 & 1,00 & 0,00 & 0,00 & .. \\
\hline 1975 & 1.401 & 4.739 & 6,14 & 0,16 & 15,63 & 3,00 & 2,00 & 200,00 & 0,08 \\
\hline 1976 & 1.960 & 5.129 & 7,09 & 0,15 & 15,46 & 2,00 & $-0,33$ & $-33,33$ & $-0,46$ \\
\hline 1977 & 1.753 & 5.796 & 7,55 & 0,06 & 6,49 & 21,00 & 9,50 & 950,00 & 0,01 \\
\hline 1978 & 2.288 & 4.599 & 6,89 & $-0,09$ & $-8,77$ & 17,00 & $-0,19$ & $-19,05$ & 0,46 \\
\hline 1979 & 2.261 & 5.070 & 7,33 & 0,06 & 6,44 & 72,00 & 3,24 & 323,53 & 0,02 \\
\hline 1980 & 2.910 & 7.910 & 10,82 & 0,48 & 47,59 & 67,00 & $-0,07$ & $-6,94$ & $-6,85$ \\
\hline 1981 & 4.703 & 8.933 & 13,64 & 0,26 & 26,03 & 5,00 & $-0,93$ & $-92,54$ & $-0,28$ \\
\hline 1982 & 5.746 & 8.843 & 14,59 & 0,07 & 6,98 & 1,00 & $-0,80$ & $-80,00$ & $-0,09$ \\
\hline 1983 & 5.728 & 9.235 & 14,96 & 0,03 & 2,56 & 1,00 & 0,00 & 0,00 & na \\
\hline 1984 & 7.134 & 10.757 & 17,89 & 0,20 & 19,57 & 7,00 & 6,00 & 600,00 & 0,03 \\
\hline 1985 & 7.958 & 11.344 & 19,30 & 0,08 & 7,89 & 1,00 & $-0,86$ & $-85,71$ & $-0,09$ \\
\hline 1986 & 7.457 & 11.105 & 18,56 & $-0,04$ & $-3,83$ & 6,00 & 5,00 & 500,00 & $-0,01$ \\
\hline 1987 & 10.190 & 14.158 & 24,35 & 0,31 & 31,17 & 30,00 & 4,00 & 400,00 & 0,08 \\
\hline 1988 & 11.662 & 14.335 & 26,00 & 0,07 & 6,78 & 22,00 & $-0,27$ & $-26,67$ & $-0,25$ \\
\hline 1989 & 11.625 & 15.792 & 27,42 & 0,05 & 5,46 & 63,00 & 1,86 & 186,36 & 0,03 \\
\hline 1990 & 13.595 & 21.047 & 35,26 & 0,29 & 28,62 & 133,00 & 1,11 & 111,11 & 0,26 \\
\hline 1991 & 14.716 & 22.871 & 34,64 & $-0,02$ & $-1,76$ & 108,00 & $-0,19$ & $-18,80$ & 0,09 \\
\hline 1992 & 15.343 & 29.428 & 37,59 & 0,09 & 8,50 & 318,00 & 1,94 & 194,44 & 0,04 \\
\hline 1993 & 18.106 & 23.270 & 44,77 & 0,19 & 19,11 & 135,00 & $-0,58$ & $-57,55$ & $-0,33$ \\
\hline 1994 & 21.599 & 35.710 & 41,38 & $-0,08$ & $-7,58$ & 152,00 & 0,13 & 12,59 & $-0,60$ \\
\hline 1995 & 23.245 & 43.628 & 57,31 & 0,39 & 38,51 & 53,00 & $-0,65$ & $-65,13$ & $-0,59$ \\
\hline 1996 & 26.260 & 48.560 & 66,87 & 0,17 & 16,69 & 31,00 & $-0,42$ & $-41,51$ & $-0,40$ \\
\hline 1997 & 26.881 & 45.921 & 74,82 & 0,12 & 11,88 & 18,00 & $-0,42$ & $-41,94$ & $-0,28$ \\
\hline 1998 & 26.587 & 40.226 & 72,80 & $-0,03$ & $-2,70$ & 12,00 & $-0,33$ & $-33,33$ & 0,08 \\
\hline 1999 & 27.775 & 54.503 & 66,81 & $-0,08$ & $-8,23$ & 48,00 & 3,00 & 300,00 & $-0,03$ \\
\hline 2000 & 27.775 & 54.503 & 82,28 & 0,23 & 23,15 & 9,00 & $-0,81$ & $-81,25$ & $-0,28$ \\
\hline 2001 & 31.334 & 41.399 & 72,73 & $-0,12$ & $-11,60$ & 6,00 & $-0,33$ & $-33,33$ & 0,35 \\
\hline 2002 & 36.059 & 51.554 & 87,61 & 0,20 & 20,46 & 1,00 & $-0,83$ & $-83,33$ & $-0,25$ \\
\hline 2003 & 47.253 & 69.340 & 116,59 & 0,33 & 33,08 & 9,00 & 8,00 & 800,00 & 0,04 \\
\hline 2004 & 63.167 & 97.540 & 160,71 & 0,38 & 37,84 & 11,00 & 0,22 & 22,22 & 1,70 \\
\hline 2005 & 73.476 & 116.774 & 190,25 & 0,18 & 18,38 & 16,00 & 0,45 & 45,45 & 0,40 \\
\hline 2006 & 85.535 & 139.576 & 225,11 & 0,18 & 18,32 & 15,00 & $-0,06$ & $-6,25$ & $-2,93$ \\
\hline 2007 & 107.272 & 170.063 & 277,33 & 0,23 & 23,20 & 7,00 & $-0,53$ & $-53,33$ & $-0,43$ \\
\hline 2008 & 132.027 & 201.964 & 333,99 & 0,20 & 20,43 & 10,00 & 0,43 & 42,86 & 0,48 \\
\hline 2009 & 102.143 & 140.928 & 243,07 & $-0,27$ & $-27,22$ & 5,00 & $-0,50$ & $-50,00$ & 0,54 \\
\hline 2010 & 113.883 & 185.544 & 299,43 & 0,23 & 23,19 & 4,00 & $-0,20$ & $-20,00$ & $-1,16$ \\
\hline 2011 & 134.907 & 240.842 & 375,75 & 0,25 & 25,49 & 19,00 & 3,75 & 375,00 & 0,07 \\
\hline 2012 & 152.462 & 236.545 & 389,01 & 0,04 & 3,53 & 73,00 & 2,84 & 284,21 & 0,01 \\
\hline 2013 & 151.803 & 251.661 & 403,46 & 0,04 & 3,72 & 7,00 & $-0,90$ & $-90,41$ & $-0,04$ \\
\hline 2014 & 157.610 & 242.177 & 399,79 & $-0,01$ & $-0,91$ & 21,00 & 2,00 & 200,00 & 0,00 \\
\hline 2015 & 143.839 & 207.234 & 351,07 & $-0,12$ & $-12,18$ & 171,00 & 7,14 & 714,29 & $-0,02$ \\
\hline 2016 & 142.557 & 198.610 & 341,17 & $-0,03$ & $-2,82$ & 287,00 & 0,68 & 67,84 & $-0,04$ \\
\hline
\end{tabular}

The number of terrorist incidents was obtained from the Global Terrorism Database (2017). One or more mortal occurrences of terrorism have been included in the analysis. While there were a few terrorist incidents in the early 1970s, it is seen that this figure reached to 70 by the end of 1970s. After the 1980 military coup, the number of terrorist incidents began to decline again. In the 1990s, terrorist incidents are seen to increase again. For example, in 1990, the number of terrorist attacks increased from 133 to 152 in 1999. During this period, in Turkey, the PKK and leftist D-HKPC and at least 10 different religious characteristics terrorist group activity is observed. It is seen that terror attacks have decreased in the beginning of 2000s, but since 2012, terrorist incidents have increased dramatically due to the internal turmoil in Iraq and Syria. In 2016, the number of terrorist attacks reached 287 (See figure 2). 
Figure: 2

Turkey Foreign Trade and Terror Index (1970-2016)

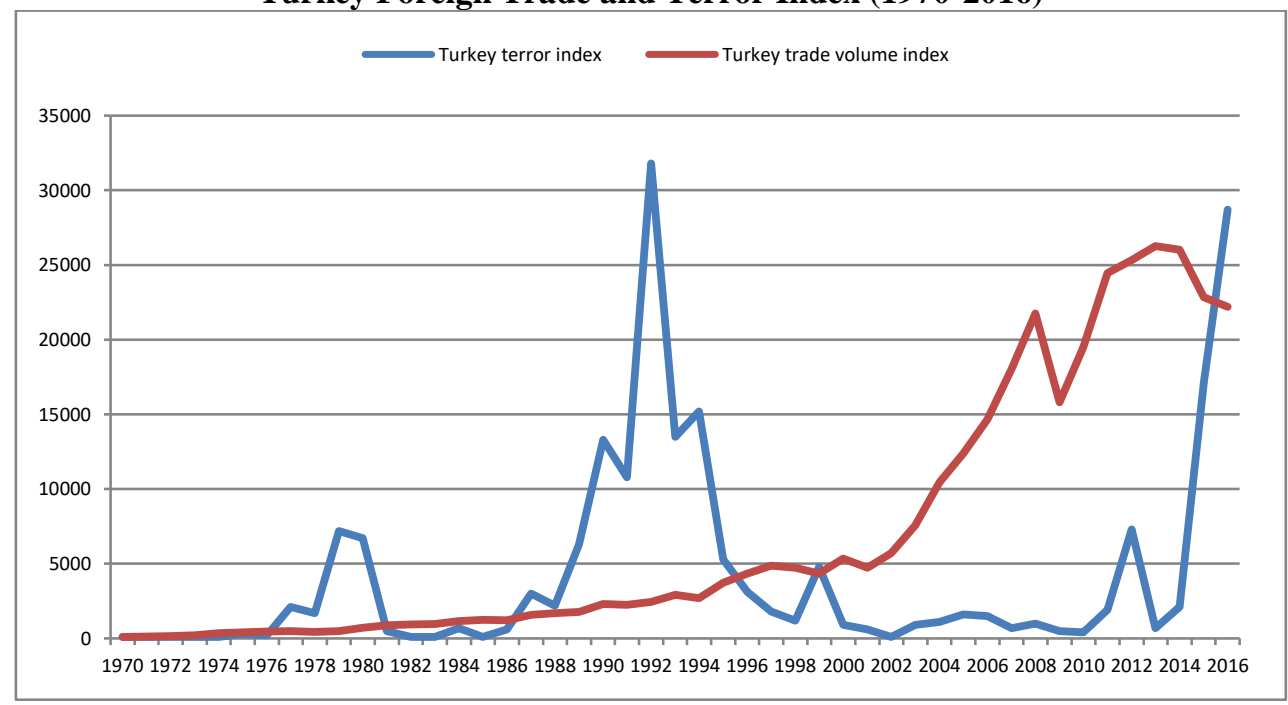

Table 2 shows the details of TTEI of economy of Turkey in 1970-2016. This measures the responsiveness of terrorist attacks to the international trade. Between these years only 1980, 2004, 2006 and 2010 years are more sensitive according to our analysis. The value of TTEI for these years $-6.85,1.70,-2.93$ and -1.16 , respectively. Since 1980 was an extraordinary year (both the foreign trade regime has changed, and it has been a military coup), a different result can be expected. In other words, during the 46 years analysis, only 3-4 years are sensitive, remaining 43 years are less sensitive. Therefore, our analysis Turkish economy indicates that terrorist attack cannot negatively affects the international trade.

\section{Conclusion}

This study deals with the effects of terrorism on foreign trade. To measure this effect, between the years of 1970-2016, Turkey foreign trade and terrorism data were analyzed by considering elasticity. Accordingly, Turkey's foreign trade is not sensitive to terrorism. This means, foreign trade is not affected by terrorist activities. Why such a result is obtained?

The first possibility concerns terrorist data. In all existing analyzes, terrorist attacks are not distinguished in terms of violence. Attacks that are not serious and attacks that lead to loss of life have different effects on economic activity but are collected together and the analysis is of equal weight. The clash of terrorists and security forces in rural areas may not have much effect on economic activities in large cities. Therefore, since the acquisition of terror data is problematic, it prevents you from fully measuring the effects of terrorist attacks on trade. This is more theoretical than empirical. 
Secondly, terror is concentrated in particular geographical regions, like Middle East, South-East Asia etc. Trade in the countries in these conflict zones is likely to be challenging, but since the impact is already long-lasting, new terrorist attacks will not have an impact on economic behavior. Because costs have already been foreseen and internalized and trade levels have been suppressed for a long time. Therefore, if an attempt is made to estimate the effect of terrorist attacks on the trade at this time, it is unlikely to find evidence supporting negative effects. This does not mean that terrorism has not diminished trade, but it means localizing the effect in the long run.

Thirdly, with the globalization, the volume of trade in international trade has grown enormously and the markets have become more competitive. Therefore, if you are withdrawn from a market due to terrorism, it will be filled by others immediately. For the companies operating in the global market, which is becoming more and more competitive, the cost of abandoning trade due to terrorism may exceed its usefulness. Governments are also facing a balance of pressure between counter-terrorism measures and expanding trade. As the most common example, Li (2009:184) shows the rapid return of the US stock market to the pre-9/11 level. Another example, three to four hours after the terrorist attacks in Turkey from Ataturk Airport made the start of the flight and a day after the rupture from flight records indicate that this rapid adaptation. As evidenced by the experiences, terror attacks cause temporary delays in trade, but there is a rapid return and recovery after attacks. Therefore, statistical studies may not be able to detect damages.

On the whole, economic data does not support the fact that terrorist attacks adversely affect foreign trade, but this does not mean that trade has not diminished. Therefore, the effect of terrorism on trade varies according to the circumstances.

\section{References}

Braithewaite, A. \& Q. Li (2007), "Transnational terrorism hot spots: Identification and impact evaluation”, Conflict Management and Peace Science, 24(4), 281-296.

Enders, W. \& T. Sandlers (1999), “Transnational Terrorism in the Post-Cold War Era”, International Studies Quarterly, 43(1), 145-67.

Fratianni, M. \& H. Kang (2006), "International Terrorism, International Trade, and Borders", in: M. Fratianni (ed.), Regional Economic Integration (Research in Global Strategic Management, Vol. 12), Emerald Group Publishing Limited, Chapter 10, $203-223$.

IEP - The Institute for Economics and Peace (2017), <http://economicsandpeace.org/reports/>, 15.05.2017.

Global Terrorizm Database (2017), <http://www.start.umd.edu/gtd>, 10.052017.

Gries, T. \& T. Krieger \& M. Daniel (2011), "Causal Linkages between Domestic Terrorism and Economic Growth", Defence and Peace Economic, 22(5), 493-508.

Khan, A. \& Z. Yusof (2017), "Trade-Terrorist Evaluation Index (TTEI)", Quality and Quantity, 51(1), $365-375$.

Li, Q. (2009), The Effect of Transnational Terrorism on Bilateral Trade, <http://People.tamu.edu/quanli/paper/Elgar-2009.pdf>, 10.09.2017, 169-185. 
Mc Kenna, J. (2005), Implication of Transnational Terrorism on Intenational Trade, <www.econ.duke.edu/dje/2006/McKenna.pdf> 10.03.2017.

Mirza, D. \& T. Verdier (2006), "International Trade, Security and Transnational Terrorism: Theory and Empirics", World Bank Policy Research Working Paper, 4093.

Nitsch, V. \& D. Schumacker (2004), “Terrorism and International Trade: An Empirical Investigation”, European Journal of Political Economy, 20(2), 423-433.

Pham, C.S. \& H. Doucouliagos (2017), “An Injury to one is an injury to all: Terrorism's Spillover Effects on bilateral Trade”, Discussion Paper, IZA Institute of Labour Economics, IZA DP NO. 10859.

Sezgin, Ş. \& N. Gündüz \& S. Sezgin (2008), "Güneydoğu Terör Olaylarının Ekonomik Sonuçları”, Akademik Incelemeler, 3(1), 1-16.

Sezgin, Ş. \& S. Sezgin (2011), "Economics of Conflict: Turkey's experience”, in: D.L. Braddon \& K. Hartley (eds.), Handbook on the Economics of Conflict, Edward Elgar Publishing Ltd., USA and UK, 362-376.

Sezgin, Ş. \& S. Sezgin (2018), "Orta Doğu Ülkelerinde Ticaret Hacmi ve Terör İlişkisi,” $1^{\text {st }}$ International Congress on Politics, Economics and Financial Analysis - 2018 (PEFA'18), April 26-28, Aydın, Turkey.

World Development Indicators (2017), <www.dataworldbank.org>, 10.05.2017. 